\title{
RESISTANCE AND REINVENTION OF THE SUBJECT IN JACKIE KAY'S TRUMPET
}

\author{
A. Lâmia Gülçur \\ Boğaziçi University
}

In her work Methodology of the Oppressed, Chela Sandoval claims that although inequities in material sources and subordination by race, class, nation, gender and sex continue to operate under the protection of law and order, a new kind of psychic penetration that respects no previous boundaries is evolving. She argues that "Mutation in culture, today, makes new forms of identity, ethics, citizenship, aesthetics and resistance accessible" (36.7).

In short, the contemporary schizophrenia of cultural globalization opens up a liberating mode of consciousness for the scapegoated, marginalized, enslaved, and colonized of every community. These groups have taken this schizophrenia as an opportunity for re-cognition, as turning points in their life history. They have discovered that freedom and triumph have been forbidden to them and have turned toward something else to be, developing modes of perceiving, making sense of, and acting upon reality all of which are the basis of effective forms of oppositional consciousness in today's world.

Influenced by a newspaper article upon the death of jazz pianist Billy Tipton, a white woman who lived her life as a man, Kay constructs Joss Moody, a black Scottish trumpeter who lived his life as a man and was discovered to be anatomically female 
after he died. Trumpet is about the life and death of Joss Moody or Josephine Moore as told by the various people who have come into contact with him. The novel is set in the aftermath of Joss's death. The only character who knows or has known about his being a woman is Millie, his grieving widow, who is white. Joss's story is told from her point of view and their adopted son Colman's, who didn't know the true nature of his father's sex. Other ordinary people too add to the music, some of them have known Joss, while others have been exposed to his woman's body but not to his personality. Kay herself says the novel is all about the effect that his secret has on the ordinary lives of the various characters: the registrar, the drummer who worked with Joss, the cleaner, the tabloid journalist who plans to make millions on the story of his life, his girlhood friend who loved him when he was a little girl. She claims that she wanted her novel to resemble jazz music where all the notes blend into one another. Through this blending, she traces the affirmations and constructions of selfhood in order to parody and expose the discontinuities of dominant myths of nation and sex/gender systems within a series of dislocated familial, sexual and racial identities. Kay carefully maps out the racial context of the British black, although she claims that race is not the pivotal point of the novel.

When musing over about her wedding, Millie recalls that her family almost didn't come. She reminisces:

I didn't want to believe it of them. I didn't want to believe my own mother could be prejudiced in that way. When I told her I was marrying Joss, she said she had nothing against them, but she didn't want her own daughter. People should keep to their own, she said. It wasn't prejudice, it was common sense, she said. Then she said the word, 'Darky,' I don't want you marrying a 'Darky' (27).

Colman, the adopted son, also has memories. One of them is what his parents have told him that the agency from which he was adopted was extremely pleased given his color.

He states:

London was seething racist. I don't remember much about Glasgow. ...My father kept telling me I was Scottish. Born there. But I didn't feel Scottish. Didn't feel English either. Didn't feel anything. My heart is a fuck- 
ing stone (51).

One of his earliest memories is an incident that took place on a bus when a black man got on and a passenger called him an ape. When his mother got angry:

[The man said] 'No wonder' or something. And the black man who had been called an ape....was just sitting with his eyes low, looking at the bus floor (549).

Colman is, in fact, quite often reminded of his color. He says of himself that he always got lost. Got himself into fights with [when he was traveling] the railman, the other customer.

It is not easy to travel in this country. Black guys like him. People always think they are going to be wrong or they've done something wrong or they're lying, or about to lie, stealing or about the steal. It's no fucking joke just trying to get about the place with people thinking bad things about you all the time. He knows that they think these things. ... They are wary of him, scared of him, uptight (189).

The scene, in short, is the post imperial British site of hybridity, transculturation and or multiculturation. And Kay draws all these together to uncover, represent and critique the cultural differences, the differences of ethnicity, race, belonging, cultural memory, gender, sexual identity, class and location which are central to her country. She delineates a set of critical points within which the individual seeking to transform dominant and oppressive power can constitute himself as a resistant and oppositional subject. Sandoval claims that "These points are orientations deployed by those subordinated classes who seek subjective forms of resistance other than those determined by the social order itself. These orientations can be thought of as repositories within which subjugated citizens can either occupy or throw off subjectivities in a process that at once enacts and decolonizes their various relations to their real conditions of existence" (53). The success of the individual in this aspect of resistance rests on his developing survival skills into technologies for reorganizing himself and his collective dreams for empowerment into images turned fact.

Joss's re-cognition is all-embracing; he seems to believe that the imaginary construction of identity is true of race and nationality as well as of gender and sexuality. He claims to be Black and Scots since nationality is neither essential nor empirical; it is as 
Benedict Anderson puts it, an "imagined community." When Colman asks him about roots and lineage, he remembers Joss telling him that they were related and that it was the same for the band:

He felt that way too about the guys in his bands, that they were all part of some big family. Some were white some black. ... He said you make up your own bloodline, Colman. Make it up and trace it back. Design your own family tree - what's the matter with you? Haven't you got imagination? (59).

And then he presents Colman with different stories of his father, that he was an American and came to Scotland because of segregation, that he was Caribbean, that he just came off a ship from Africa. He says:

Any of these stories might be true, Colman. ....Which one? I said. Which one is true? Doesn't matter damn, he said. You pick. You pick the one you like best and that one is true (59).

Joss's strategies of subversion reflect the defiant demand of the colonized to recognize culture as artifact, an interested construction reflecting values of social constituencies rather than productions of nature and God. He is the product of the oppositional forms of consciousness and behavior that emphasize the transience of reality itself. His body is marked with the stamp of Africa and yet that too is a fantasy. Moody's earliest hit song is called "Fantasy Africa", and the title captures one of the essential messages of the book:

"Every black person has a fantasy Africa,' he'd say. "Black British people, Black Americans, Black Caribbeans, they all have a fantasy Africa, its all in the head" (34).

And even Colman admits that he has no place in Africa: It feels false to him, mates that get dressed up in African gear, wank on about being African with a fucking cockney accent, man. Back to Africa is just as unreal as far as Colman is concerned. He's never been to Africa, so how can he go back? (191).

However, he does realize the need for reinvention of identity within the unbending context of his society. He observes:

What is this thing with hair? ... White guys aren't in- 


\section{Gülçur-Resistance and Reinvention}

terested in their hair as far as he can see. Black guys keep reinventing themselves through hairstyles. ... His father liked going to a barber that was good at cutting black hair ... They'd get done together. An initiation ceremony (183).

But Joss reinvents himself within the parameters of gender as well since no one questions whether either Joss or Colman is black or Scottish or demands certainty as to what they are, yet this is precisely what is demanded in terms of Joss's sexed body. However, as Judith Butler claims: "...there is no gender identity behind the expressions of gender; that identity is performatively constituted by the very "expressions" that are said to be its result" (25). In other words, the truth of gender is produced through the regulatory practices that generate coherent identities through the matrix of coherent gender norms which require that certain kinds of identities where gender does not follow from sex cannot exist. "Follow" claims Judith Butler "in this context is a political relation of entailment instituted by the cultural laws that establish and regulate the shape and meaning of sexuality" (17). Joss uses the oppositional strategies of the oppressed to resist this dominant ideology or myth. He recognizes that the social meaning and ideology are form and not content. Signification exists only in relation to another, opposing signification - as in the case of the colonized and the colonizer who is signified through the negation of its other-gender roles are all established through their difference in the binary oppositions, though as Irigaray aptly suggests both "the subject and the other are masculine mainstays of a closed phallogocentric signifying economy that achieves its totalizing goal through the exclusion of the feminine altogether" (Butler 9). In such a context the agents of resistance are again created by this signifying-through-negation economy. Bhabha stresses the creation of "hybrids." He posits that "the production of meaning requires these two places be mobilized in the passage through a third space" (208). Pointing to the fact that in this third space "... the meaning and symbols of culture have no primordial unity and fixity; that even the same signs can be appropriated, translated, re-historicized and read anew" (ibid.), he foresees the possibility of enunciation in this third space. Joss Moody's resistance as a perfectly conscious "hybrid" or "mutation" constitutes the very proof that signs of gender can be "read anew". Here reading 
Joss Moody as a "hybrid" instead of a woman who chose to be a man is more appropriate. I argue that he is in the third space, nor woman nor man anymore. He lives and dies as a mutation. This is the realm of what is "undefined", what is impossible to appropriate because it escapes all definitions of sexuality and gender. Joss is neither a man nor a woman; neither a homosexual nor a bisexual. He/she includes all these definitions and frees himself/herself from all of them as we see in the course of the novel.

To the registrar Millie looks just like any other widow: She had the widow's sad skin. ... A widow who had come to get the piece of paper that would tell her, because she still didn't believe it, that her husband had really died. ... He asked the woman if Joss Moody ever formally changed her name to Joss Moody. The woman told him she didn't think so. In other words, Mr. Sharif concluded, one day Josephine Moore just plucked the name Joss Moody out of the sky and called himself this name and encouraged others to do likewise. ... The woman nodded, smiling shyly, proud of her spouse's achievement. .... He dipped his marbled fountain pen in the black Indian ink and wrote the name loss Moody on the death certificate (80-81).

Millie's reaction, when she first met Joss, was very much the same. She remembers asking him whether Joss Moody was his real name since it sounds like a name that someone would make up in anticipation of being famous: "He laughs at that and tells me he is going to be famous. I laugh too, nervously. I know he is going to be famous also" (139). And he does become famous - this tall, handsome black musician.

Joss's life as a man is irreproachable. Judith Butler claims that: "Gender is the repeated stylization of the body, a set of repeated acts within a highly rigid regulatory frame that congeal over time to produce the appearance of substance, of a natural sort of being" (33). Joss subverts the rigid frame by following the very acts that create the appearance of what Butler calls a "naturalistic necessity" (33). The substantive effect of gender is performatively produced. His anatomy interferes in the site at the very beginning of his relationship with Millie - when he has to expose his body to her. Otherwise he is a loving husband and 


\section{Gülçur-Resistance and Reinvention}

father. Millie says:

My husband died. I am now a widow. ...My husband died, I am now a widow. ... Why can't they understand how ordinary that is? ...I managed to love my husband from the moment I clapped eyes on him till the moment he died. ... I managed to be faithful, never to be interested in another man. I managed to be loyal, to keep our private life where it belonged. ... I know I loved being the wife of Joss Moody (205-206).

And the reactions of those who have to deal with Joss's body are much the same. Dr. Krishnamurty who comes to give the death certificate for the man and discovers he has breasts thinks on her way home that they looked strange, preserved, that they weren't real breasts at all. "At least not women's breasts" (43).

Holding, the funeral director, has a similar reaction when he undresses the body and cannot find a penis.

The whole absence made Albert Holding feel terribly anxious, as if he had done something wrong. As if he was not doing his job properly. He had never had a man turn into a woman before his very eyes. He felt it to be one of those defining moments in his life that he would be compelled to return to again and again. ...today, he had a woman who persuaded him, even dead, that he was a man, once he had his clothes on ( 109 , $111,116)$.

Colman's fury too subsides when he sees his father dressed in a suite once more. "He looked all right in that blue suite. He looked normal again. Dead; but normal. Better" (72).

These reactions validate or, actually, go beyond Sandoval's claims of mutation in culture opening up new possibilities regarding identity. The doctor, the funeral director and Colman all consent to accept Joss as a man in spite of his woman's body. It is not only a matter now of how Joss perceived himself but how others, besides Millie, decide to perceive his gender.

The outside world calls it "Living a Lie" (95). But Millie feels that she was living a life. "Hindsight is a lie" (95), she claims, and, this is the reason she has never told Colman, since there was nothing to tell. Josephine Moore is the third person for Joss Moody. Someone else he talked about in the third person and whom he wanted left alone. Joss has not lived a lie, but rather he has lived in disguise, a "real disguise", as Fanon calls it, that 
enables survival.

The only reality for Joss Moody seems to be what he has created of himself and the freedom of his music. Jazz, the music of improvisation and reinvention, is the language of what Joss feels to be reality. Colman remembers:

Music was the way of keeping the past alive, his father said. There's more future in the past than there is in the future.... Black people and music; what would the world be without black people and music. Slave songs, work songs, gospel, blues, ragtime, jazz. ... All blues are stories. Our stories, his father said, our history. You can't understand the history of slavery, without knowing about the slave songs (191).

Music, for Joss, is the "abyss" that Barthes formulates. The zero-degree that Derrida designates as différance, "the bottomless chessboard where being is set" into play (154). Différance solicits the structure of every kind of human order. Its ascent ruptures older meanings and discloses in its activity new openings for interpreting and being. There is pain involved in the crossing to this no-place/utopia maintains Barthes. It is whatever is not expressible through words but accessed through poetic modes of expression such as music. It is a painful crossing to a chiasmus where new kinds of powers are evoked as the body dissolves. Barthes warns that this falling, flowing and melting, the subjectivity in this abyss also undergoes a sincere form of "bliss", that violent pleasure which shatters cultural identity or ego. It is an arrival at a utopian no-place where everything is possible - but only in exchange for the pain of the crossing (10). It is the differential consciousness in Sandoval's words "any system of signification which permits breaking through whatever controls, crossing over to another world" (139-140).

This abyss, différance, or differential consciousness, is what Joss finds in his world of music:

When he gets down, and he doesn't always get down deep enough, he loses his sex, his race, his memory. He strips himself bare, takes everything off, till he's barely human. ... Getting there is painful. He has to get to the centre of a whirlwind, screwballing in musical circles till he is very nearly out of his mind. ...he sometimes fears he'll never return sane... He goes down, swirling 
and whirling till he's right clown at the very pinpoint of himself. ... He could be the migrant. The dispossessed. He can't stop himself changing. Running changes. He unwraps himself with his trumpet. Down at the bottom, face to face with the fact that he is nobody. ... Playing the horn is not about being somebody coming from something. It is about being nobody coming from nothing. The horn ruthlessly strips him bare till he ends up with no body, no past, nothing (131-135).

This is the reality of Joss's existence. Colman observes: He looked real enough playing that horn in those smoky clubs; he looked real and unreal like a fantasy of himself. All jazz men are fantasies of themselves, reinventing the Counts and Dukes and Armstrongs, imitating them (190)

Even when we hear the voice of the dead; a letter from Joss fails to fix the truth. Joss writes:

Someone painted a picture of my father which I've left for you. ... The picture is called Mumbo Jumbo... He's not given a name. Even the name he was given, John Moore, was not his original name. That's the thing with us: we keep changing names. We've all got that in common (276).

Kay deliberately chooses not to disclose the initial impulse that led Josephine Moody to recreate himself as a black Scots "man". But we have, as readers, to recognize the resistance inherent in this kind of hybridity. As Butler says: "Inasmuch as 'identity' is assured through the stabilizing concepts of sex, gender, and sexuality, the very notion of "the person" is called into question by the emergence of those "incoherent" or discontinuous" gendered beings who appear to be persons but who fail to conform to the gendered norms of cultural intelligibility by which persons are defined" (17). As a result, the important voices here finally emphasize that identity is not what we are born with but what we decide to make it - a manifestation of our desires.

To conclude, resisting essentialist stances to identity formation, Kay's Trumpet adopts the anti-essentialist discourse and carries it to extremes. Loaded with post-modern and postcolonial references to fragmentation, reinvention, open text, difference, and hybridity and, to a certain extent, mimicry, the 
novel delves into the depths of the "idea of the oppressed" where a great source of empowerment is discovered.

\section{References}

Barthes, Roland. 1977. Image/Music/Text. Trans. Stephen Heath. New York: Hill and Wang.

Bhabha, Homi K. 1985. "Signs Taken for Wonders." The Post-Colonial Studies Reader. Ecls. Bill Ashcroft, Gareth Griffiths, Helen Tiffin. London: Routledge.

Butler, Judith. 1990. Gender Trouble: Feminism and the Subversion of Identity. New York: Routleclge.

Derricla, Jacques. 1973. "Différance," in Speech and Phenomena and Other Essays on Husserl's Theory of Signs. Evanston: Northwestern University Press.

Kay, Jackie. 1998. Trumpet. London: Picador.

Sancloval, Chela. 2000. Methodology of the Oppressed. Minnesota: University of Minnesota Press. 